\title{
基于半导体纳米线/锥形微光纤探针的被动式近场光学扫描 成像"
}

窦琳 1) 麻艳娜 1)† 顾兆麒 1) 刘家䑣 1) 谷付星 1)†

1) (上海理工大学 光电信息与计算机工程学院, 上海 200093)

\section{摘 要}

中文摘要部分. 本文结合近场扫描结构和纳米线-微光纤耦合技术, 提出 了一种基于硫化镉纳米线/锥形微光纤探针结构的被动近场光学扫描成像 系统。该系统采用被动式纳米探针, 保留了纳米探针对样品表面反射光 的强约束优势。其理论收集效率为 $4.65 \%$ ，相比于传统的金虐镀腜近场 探针收集效率提高了一个数量级, 可有效提高扫描探针对样品形貌信息 的检测能力; 而后通过硫化镉纳米线与微光纤之间高效的修逝场耦合将 检测的光强信号传输到远场进行光电探测, 最终实现对目标样品形貌的 分析成像, 其样品宽度测量误差在 $7.28 \%$ 以内。该系统不需要外部激发 光路, 利用显微镜自身光源进行远场照明, 被动扫描探针仅作为样品表 面反射光的被动收集系统。本文基于半导体纳米线/锥形微光纤探针的被 动式近场光学扫描成像方案, 可有效降低探全的制备难度和目标光场的 检测难度, 简化扫描成像的结构, 为近场光学扫描显微系统之后的发展 提供新的思路。

关键词: 近场光学扫描; 被动显微成像技术; 纳米线/微光纤光学探针; 硫化镉 纳米线; 修逝场耦合

PACS: $07.79 . \mathrm{Fc} ; 42.30 . \mathrm{d} ;$ 42.79.Gn.

基金: 国家自然科学基金犹秀青年科学基金项目（批准号：6212200740）。

†通讯作者.E-maril mayanna@usst.edu.cn

†通讯作者.E-1naj gufuxing@usst.edu.cn

\section{1 引言}

显微技术实现了人类在微米甚至纳米量级的视觉分辨, 极大地促进了对光 与物质的相互作用研究以及微结构信号探测等技术的发展。而低成本、高分辨率 的成像系统对于人类在生物科学和材料科学等领域的样品研究具有重要意义。其 中光学成像系统因结构简单且不易损伤样品等优势, 被广泛应用于多种成像系统 中 $^{[1-4]}$ 。但传统光学显微镜由于衍射极限限制, 空间分辨率仅能达到波长的一半, 
且较难获得样品的 3 维形貌轮廓信息 ${ }^{[5]}$; 而扫描电子显微镜 (scanning electron microscope, SEM)，透射电子显微镜（transmission electron microscope, TEM）和 原子力显微镜（Atomic force microscopy, AFM）等成像技术虽然可实现原子级别 的测量分辨率, 但对样品材质和工作环境的要求苛刻, 测量成本高且在一定程度 上牺牲了测量的灵活性。

近场扫描光学显微镜(Near-field Scanning Optical Microscope, NSOM)技术 [6,7]结合近场扫描结构和光电探测思路, 保留了传统光学显微镜测试条件㤗活且无 损的优势，并且可突破其衍射限制，因此作为新的多参量微观大度表征技术被广 泛研究。其中光学探针 ${ }^{[8]}$ 是近场扫描光学显微镜的核心部件, 可通过与样品表面 物理场在纳米尺度下的相互作用，将近场信息转化为可探测的远场信息，完成极 高光学和形貌分辨率的图像扫描。纳米发光探针通过纳米发光体发光性质与环境 的相关性, 结合拉雉光纤进行传输光收集, 从而实现纳米量级的传感测量。其中 采用单金纳米颗粒 ${ }^{[9-11]}$ 或者硅纳米颗粒 ${ }^{12 \gamma}$ 修饰的近场探针, 通过对光场的局部增 强, 可实现对样品的百纳米量级分辨率的测量。但由于纳米颗粒的不规则及其吸 附于光纤位置上的各向异性, 测量系统极易出现矢量信息失真。多纳米颗粒也可 以实现对近场探针的修笁仍15 , 该方案通过非线性效应增强检测信噪比，可进一 步实现几十纳米的高空间分辨率。但多粒子结构对于纳米颗粒的位置要求很高, 实现成本高难度大。此外, 科研人员还提出了纳米金字塔 ${ }^{[16]}$ 和钟楼型 ${ }^{[17]}$ 结构的近 场光学探针。上述方案均通过将散射近场的修逝波高效耦合并转化为传输波进行 检测, 但需要另外搭建激发光路或收集光路, 系统难度和复杂度都很高。

作为近场探针的修饰材料，一维纳米线材料的制备工艺更成熟，并且更易 于与微光纤结构进行高效耦合 ${ }^{[18,19]}$ 。其中金属银纳米线由于良好的单晶结构且制 备简单、成本低, 是广泛使用的纳米波导材料之一。银纳米线修饰的近场发光探 
针 ${ }^{[20,21]}$ 也成为一种新型的探针结构, 目前已经实现了高达 $1 \mathrm{~nm}$ 的拉曼增强光谱 分辨率。但由于系统采用隧穿电流反馈系统, 在近场扫描过程中需要始终保持探 针和样品的导电性; 并且银纳米线易氧化, 系统的测试条件十分苛刻。上述纳米 探针均采用主动发光方式, 即需要外部激光激发纳米粒子或纳米线形成修逝场, 为扫描系统提供检测光源。并且为了实现探针与样品表面物理场的相互作用 ${ }^{[22,23]}$, 需要严格控制待测样品与探针之间的距离。

本文提出了一种基于硫化镉（Cadmium sulfide, $\mathrm{CdS}$ ) 纳米线矢敉微光纤 探针复合结构的被动式近场光学扫描成像系统, 该方案使用显微镜自带光源做照 明，不需要复杂的探针激发光路，避免了近场检测的激发晃于扰; 同时 $\mathrm{CdS}$ 纳米 线通过对样品表面反射光的强束缚能力提高了对其表面形貌的探测能力, 而后收 集的光信号通过修逝场耦合进雉形微光纤 ${ }^{[24]}$, 传输至远场进行光电检测。相比于 发光探针结构, 该光学探针采用被动式检测, 可降低对探针一样品间距的控制需 求，并且显著降低了探测系统的结构设记复杂度; 相比于常规使用的近场扫描雉 形光纤探针结构, 纳米线针尖与样品表面光场具有更强的相互作用, 因此具有更 高的检测能力。

\section{2 系统搭建与原理分析}

半导体纳米线焳形微光纤探针的近场光学扫描成像系统的结构如图 1(a)所 示。待测样楍被置于计算机 $\mathrm{HC}$ 通过位移控制器 $\mathrm{DMC}$ 控制的三轴压电纳米位移

平台（PZT stage, PS3L40-080U-S, 上海纳动纳米）上，显微镜采用 Nikon 的 50 倍物镜, CCD 相机为 Nikon 的 DS-Ri1, 照明光源 LS 为 LHS-H100P-2, 其波长 范围为 500-750 nm, 在 600-670 nm 处光强最大。图 1(b)为图 1(a) 中虚线处放大 图, 表示显微镜扫描部分。所用纳米线/雉形微光纤探针结构由 3 维线性位移台 （M-462-XYZ-LH-M, Newport）夹持固定，探针尖端如图 1(c)。其中 CdS 纳米线 
具有矩形的横截面，其宽度和高度分别为 $350 \mathrm{~nm}$ 和 $65 \mathrm{~nm}$ 。CdS 纳米线与雉形

微光纤（SMF-28, Corning）通过范德华力及静电力稳定地结合在一起 ${ }^{[25]}$, 用于收 集样品表面的光强变化，并通过单模光纤传输到飞瓦探测器（PD，PDF10A， Thorlabs) 进行光电转换, 经过自制电放大器 EM 后进入示波器(OSC, DS11104z, RIGOL )进行检测。固定的探针与样品之间呈夹角 $\theta$, 避免出现位置抖动。该系 统采用显微镜自带的照明系统作为光源，不需要额外的外部激发光源，显著降低 了光学系统传感和检测的复杂度。在实验测量时, 首先手动粗调样品的位置和角 度, 而后通过控制器控制位移台, 精确调整样品至目标位置。扫描过程中, 根据 需要设定扫描步长和步数, 确定扫描范围, 数据则经过示波器采集并保存至上位 机系统进行分析和处理。

(a)

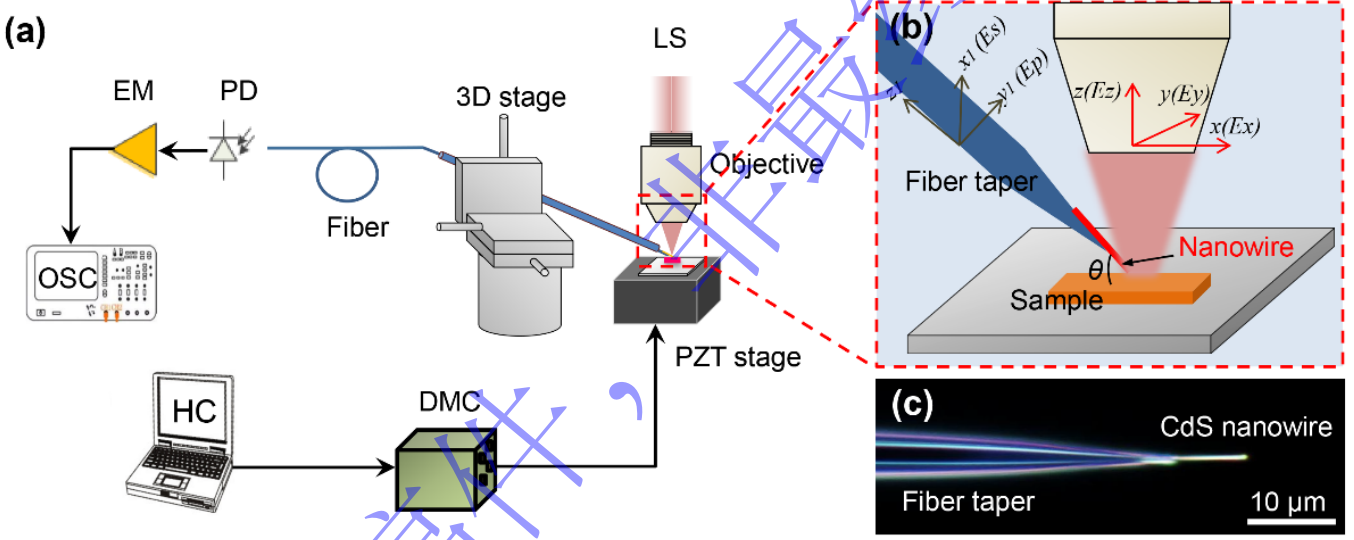

图 1 被动式近场光学扫描成像系统 (a)系统原理图 (b) 显微照明一成像部分原理图; (c) CdS 纳米线/雉形微光纤探针. $\mathrm{HC}$ : 主机, DMC:位移控制器, PZT:压电位移台, 3D stage:3 维线性 位移台, LS:照明光源, $\mathrm{PD}$ :光电转换器, $\mathrm{EM}$ : 电放大器, $\mathrm{OSC}$ :示波器

Fig. 1 Passiye near-field optical scanning imaging system: (a) Schematic diagram of the system; (b) Schematic diagram of illumination-imaging part (c) CdS nanowire/tapered microfiber structure. HC: host computer, DMC: displacement controller, PZT: piezo translation stage, LS: lighting source, 3D stage:3D linear stage, PD: photodetector, EM: electrical amplifier, OSC: oscilloscope.

实验所用光源可被看做一组经物镜聚焦后具有不同振动方向和相同光强度 的偏振光, 物镜聚焦点处主要为纵向光场分布 ${ }^{[26-28]}$ 。忽略样品的厚度折射率变化, 可采用单层膜反射模型来描述反射场: 光从折射率为 $n_{0}$ 的空气介质以角度 $\theta_{1}$ 入射 到折射率为 $n_{1}$, 厚度为 $h$ 的样品薄膜上, 空气一样品界面的折射角为 $\theta_{2}$, 基底折 
射率为 $n_{2}$ 。由于实验所用光源的入射角度很小, 该模型可近似为正入射, 即 $\theta_{1}=\theta_{2}=0$ 。因此无样品覆盖区的总反射系数可表示为 ${ }^{[29]}$ :

$$
r_{\mathrm{si}}=\frac{n_{2}-n_{0}}{n_{2}+n_{0}}
$$

而样品覆盖区的总反射系数为:

$$
\left\{\begin{array}{l}
r_{\text {sample }}=\frac{E_{o r}}{E_{o i}}=\frac{r_{1}+r_{2} e^{i \varphi}}{1+r_{1} r_{2} e^{i \varphi}} \\
\varphi=\frac{4 \pi}{\lambda} n_{1} h \cos \theta_{2}
\end{array}\right.
$$

其中 $r_{1}=\frac{n_{0}-n_{1}}{n_{0}+n_{1}}$ 为样品上表面的反射系数, $r_{2}=\frac{n_{1}-n_{2}}{n_{1}+n_{2}}$ 为下表面的反射系数, $\varphi$ 为 相邻两个反射光束间的相位差。而反射率代表了样品反射的辐射能量占总辐射能 量的百分比, 根据菲涅尔公式, 系统反射率可由反射系数得到:

$$
R=|r|
$$

仿真得到无样品覆盖区及样品覆盖区的文射率如图 2(a)所示, 可见硅基底具有更 高的光反射能力, 图 2(b)为距样品表面 $300 \mathrm{~nm}$ 处水平面的光场分布, 该时域有 限差分法(Finite difference time domainmethod, FDTD)仿真也验证了上述理论推导。

样品表面及其附近的光场对应近场, 而光纤探针通过收集这部分光场, 并经 过实验光路耦合及传输, 最终实现远场的信号接收与探测, 如图 1(a)。当采用纳 米线/雉形微光纤探针对硅基上待测样品的反射光场进行测量时, 纳米尺度探针与 样品光场之间会产生电偶极矩 $\boldsymbol{p}$, 其与样品表面光场 $\boldsymbol{E}$ 的关系由探针的极化张量 $\boldsymbol{a}$ 表示为 $\boldsymbol{p}=\boldsymbol{a} \cdot \boldsymbol{E}$ 。如图 1(b), 一般待收集的样品表面光场分为纵向分量 $\mathrm{E}_{z}$ 和面 内分量 $\mathrm{E}_{i}$ (其中 $i=x$ 或 $y$ ), 但由于远场信号仅有 $E_{s}$ 和 $E_{p}$ 两个分量, 所以在实际

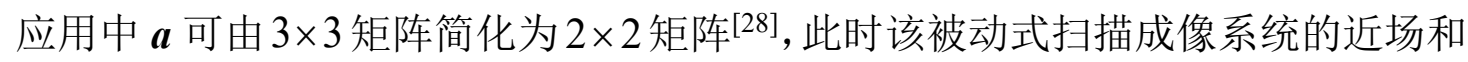
远场分量近似满足关系: 


$$
\left(\begin{array}{c}
E_{\mathrm{s}} \\
E_{p}
\end{array}\right) \propto\left(\begin{array}{ll}
\alpha_{i i} & \alpha_{i z} \\
\alpha_{z i} & \alpha_{z z}
\end{array}\right)\left(\begin{array}{c}
E_{\mathrm{i}} \\
E_{z}
\end{array}\right),
$$

由于探针针尖尺寸远小于光波长且假定结构是轴对称的, 则上述归一化张量约为:

$$
\vec{a}=\left(\begin{array}{ll}
1 & 0 \\
0 & \gamma
\end{array}\right)
$$

被动式近场探针对纵向偏振分量的响应更加敏感, 因此参数 $\gamma=a_{z z} / a_{i i}>1$ 。结合 (4)(5)式可知此时近场的纵向分量复振幅正比于待测的远场的 $E_{p}$ 分量, 即通过检 测远场信号即可得到纳米线/雉形微光纤探针所收集的样品近场信息。

$$
\text { (a) } 0.7
$$

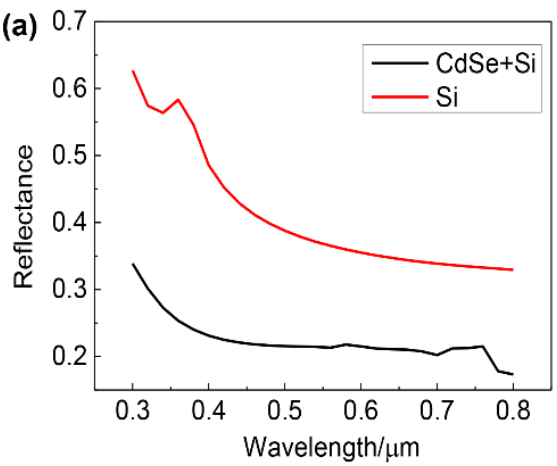

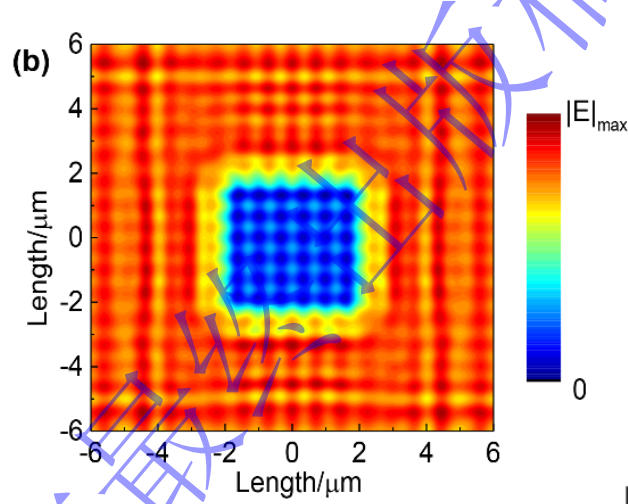

(b)

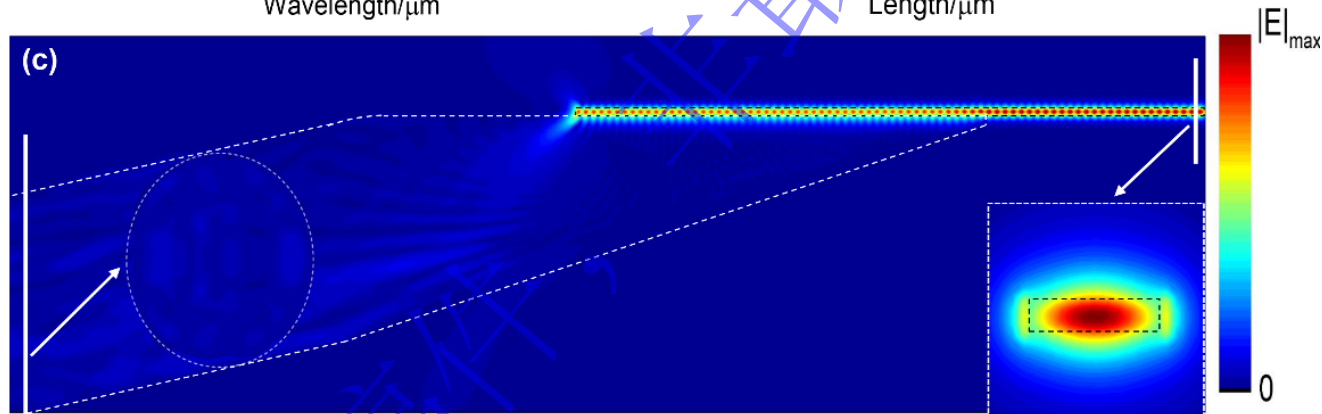

图 2 纳米线/雉形微光纽探针结构的光场模型 (a)硅基底和硒化镉-硅基底的反射率; (b) 距样品表面 $300 \mathrm{~nm}$ 处的水平面的光场分布; (c) 纳米线/雉形微光纤探针结构修逝场耦合 (右 测插图为右侧白色实线处纳米线截面的 $\mathrm{TE}$ 模光场分布, 左测圆形插图为左侧实线处雉形微 光纤探针截面光场分布)

Fig. 2. Optical field model of nanowire/tapered microfiber structure : (a) Reflectance of silicon substrate and cadmium selenide-silicon substrate; (b) Horizontal optical field distribution at $300 \mathrm{~nm}$ above the sample surface; (c) Nanowire/ tapered microfiber structure evanescent field coupling (The right inset is the TE mode optical field distribution of the nanowire cross section at the solid white line on the right, and the left circular inset is the optical field distribution of the tapered microfiber cross section at the solid line on the left)

我们还通过数值仿真验证了上述纳米线/雉形微光纤探针结构的光场模型。 FDTD 模拟的光源为波长 $600 \mathrm{~nm}$ 的圆偏振光, 探针由折射率为 1.46 的二氧化硅 锥形光纤和折射率为 2.52 的 $\mathrm{CdS}$ 纳米线组成, 样品是折射率为 2.67 的硒化镉 
（Cadmium Selenide, CdSe）纳米带, 基底是折射率为 3.95 的硅。待测样品大小 设置为 $4 \mu \mathrm{m} \times 4 \mu \mathrm{m} \times 1 \mu \mathrm{m}$ 。图 2(b)为距样品表面 $300 \mathrm{~nm}$ 处水平面的光场分布, 中间为样品放置位置。相比于样品, 反射率高的硅基底上方具有更强的光场强度。

由于探针所在光场为样品表面的反射场，其收集效率应为探针收集功率与反 射场功率的比值。对于垂直入射的光源，仿真得到探针收集功率约占光源总功率 的 $0.1 \%$, 样品的能量反射率近似为 $21.5 \%$, 因此计算得到探针的收集效率约为

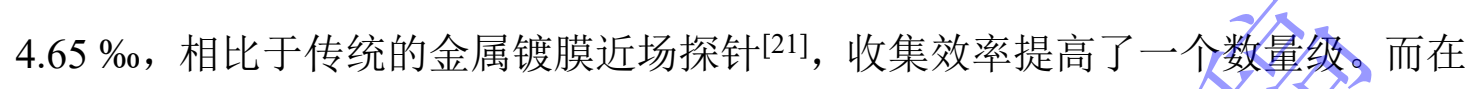
实际实验中, 光源往往不是理想的垂直入射, 此时探针所在的乍射场功率会随入 射角度变化而略有下降。对于 $20^{\circ}$ 入射的照明光源, 样品的能量反射率为 $18.9 \%$, 从而使得近场探针的收集功率同步下降。但由于探针收集效率为其收集功率与反 射场功率的比值, 结合公式(4)(5)中系统近场的纵向分量复振幅与待测远场的 $\mathrm{E}_{p}$ 分量的正比例关系，系统的探针收集效率可近似为不变。

此外, 我们还分析了光信号从纳米线端部到雉形光纤的传输特性, 根据 AFM 测量结果，仿真所用 $\mathrm{CdS}$ 纳米线宽度为 $350 \mathrm{~nm}$, 高度为 $65 \mathrm{~nm}$ 。图 2(c) 是仿真得 到的光场分布图, 对于 $5007750 \mathrm{~nm}$ 波段的光源, 其耦合系数随入射波长的增加而 提高, 又因为系统所廂光源在 $600 \sim 670 \mathrm{~nm}$ 处光强最大，仿真采用最低的 $600 \mathrm{~nm}$ 波长的光源进行耦合模拟，其传输效率为 $74.47 \%$ 。可见所制备探针可实现纳米线 和雉形光䀥之间的高效耦合与信号传输, 其耦合效率高于 $74.47 \%{ }^{[25,30]}$ 。光信号 耦合进雉形光纤之后即可通过光纤传输至远场进行信号采集与处理。该部分为后 续基于 $\mathrm{CdS}$ 纳米线/雉形微光纤探针结构的被动式近场扫描成像实验提供了理论 基础。

\section{3 实验测量及结果分析}

3.1 扫描步长和探针一样品间距的对近场成像质量的影响分析 
实验采用宽度为微米量级的 $\mathrm{CdSe}$ 纳米带作为测量样品, 首先研究了扫描步 长以及探针-样品间距对该近场扫描系统测量结果的影响。图 3(a)中分别设置扫 描步长从 $100 \mathrm{~nm}$ 降低至 $10 \mathrm{~nm}$, 扫描范围固定为 $8 \mu \mathrm{m}$ 。结果显示扫描步长越小, 边界的细节特征越明显。 $10 \mathrm{~nm}$ 和 $20 \mathrm{~nm}$ 的扫描步长均可体现样品的边界信息， 为了兼顾扫描速度和精度，后续实验选取扫描步长为 $20 \mathrm{~nm}$ 。

图 3(b)展示了纳米线/雉形微光纤探针-样品间不同的间距对扫描结果的影响。 在探针一样品间距从 $900 \mathrm{~nm}$ 减小至 $130 \mathrm{~nm}$ 过程中, 边界的光强变化越来越明显。 间距过大时，样品细节极易淹没在背景噪声中；间距过小时，探针与样品易因范 德华力和静电力吸附在一起。同样由于 $130 \mathrm{~nm}$ 和 $230 \mathrm{~nm}$ 间距条件下的扫描成像 结果类似, 为了兼顾检测难度和精度, 实验选取探钤一样品间距为 $230 \mathrm{~nm}$ 。
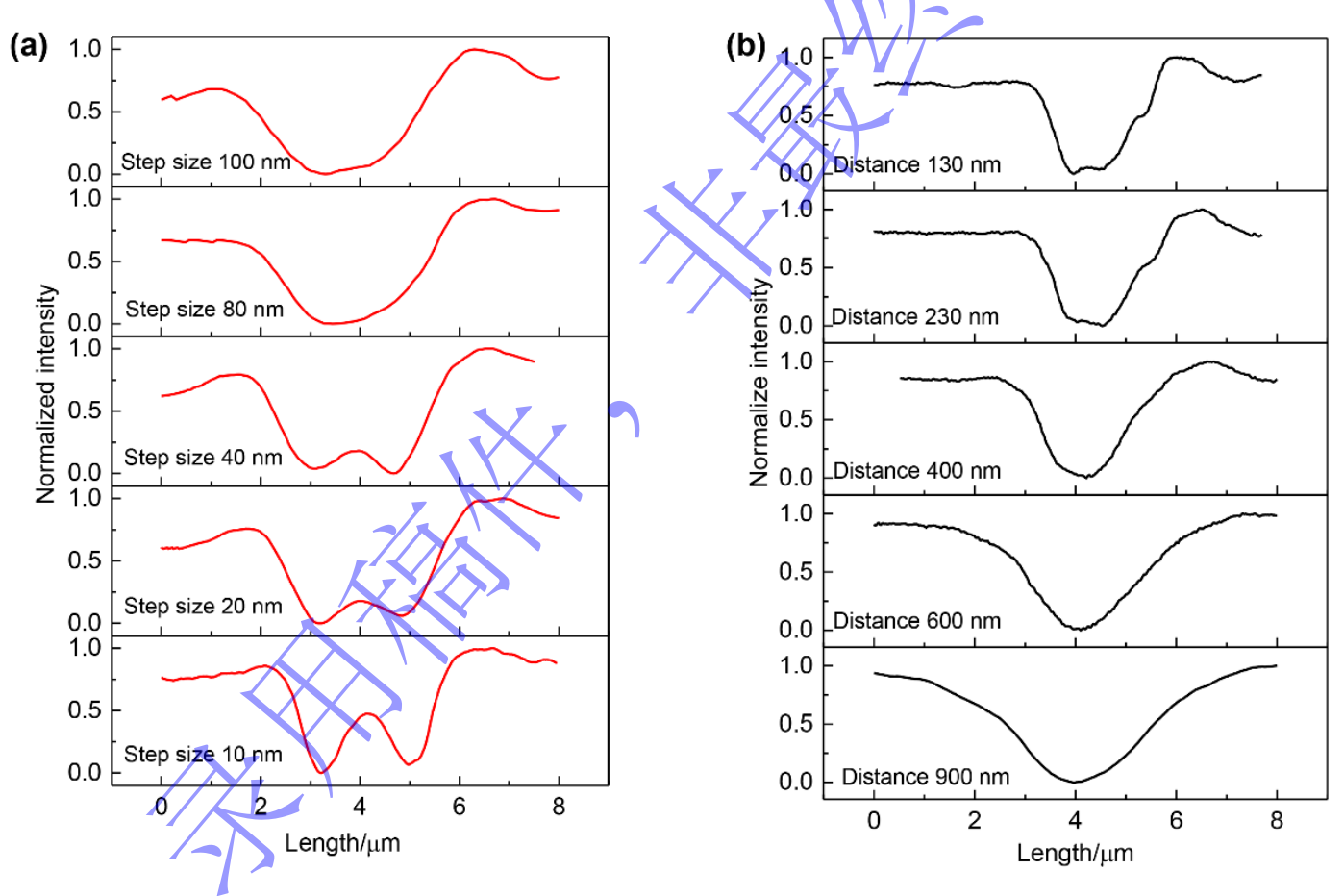

图 3 扫描步长和探针一样品间距对系统成像质量的影响 (a) 不同扫描步长条件下的扫 描结果; (b) 不同探针-样品间距条件下的扫描结果

Fig. 3. Influence of scanning step length and probe-sample distance on the image quality: (a) Scan results under different scan steps; (b) Scan results under different probe-sample distances

3.2 光纤探针扫描成像结果与分析

实验选取了三个 $\mathrm{CdSe}$ 纳米带样品 $\mathrm{S} 1-\mathrm{S} 3$ 。首先通过 AFM 对其进行扫描, 成 像结果如图 4, 其中(a), (c), 和(e)分别为不同样品在光学显微镜下面的图像; (b), 
(d), 和(f)则分别对应其虚线框部分的 AFM 测量结果, 测得样品宽度分别为 5.58 $\mu \mathrm{m}, 2.61 \mu \mathrm{m}$, 和 $2.76 \mu \mathrm{m}$ 。随后将这三个样品放在自制的被动式近场探针扫描系 统下进行测量, 分别利用雉形微光纤探针和纳米线/雉形微光纤探针收集样品表面 的反射光强变化, 结果如图 5 所示。由于半导体纳米线折射率高于二氧化硅, 通 过纳米线修饰的光场探针可实现更高精度的光强变化检测。
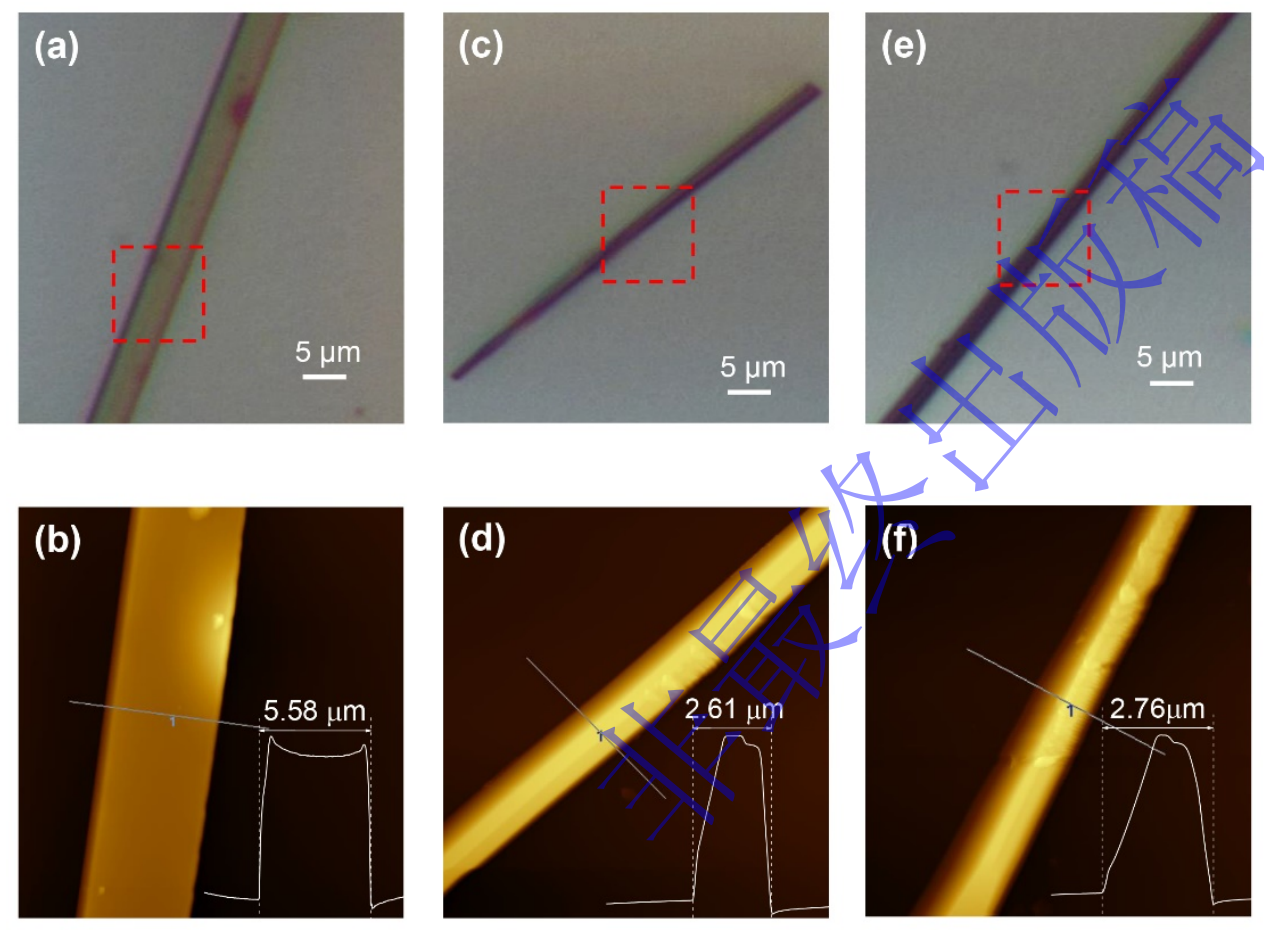

图 4 不同样品的光学显微图和AFM 扫描形貌图 (a) (b) 分别为 S1 的光学显微图和 AFM 扫 描形貌图; (c) (d) 分别为 S2 的光学显微图和 AFM 扫描形貌图; (e) (f) 分别为 S3 的光学显微 图和 AFM 扫描形貌图

Fig. 4 Optical microscope and AFM scanning morphology image of the three samples: optical microscope image (a) and AFM topography (b) of S1; optical microscope image (c) and AFM topography (d) of S2; optical microscope image (e) and AFM topography (f) of S3.

实验所用的雉形光纤探针由单模光纤熔融拉雉制成, 尖端尺寸为百纳米量级, (

与样品的夹角 $\theta$ 为 $23^{\circ}$ 。实验设定 $\mathrm{CdS}$ 纳米线伸出光纤探针长度 $10 \mu \mathrm{m}$, 如图 1(c)。

图 5(a), (d), 和 (g)分别为该纳米线/锥形微光纤探针对样品的扫描成像图, (b),

(e), 和(h)为其对应的样品宽度测量结果, (c), (f), 和(i)为雉形光纤探针的样品宽 度测量结果。由于雉形光纤探针测得光强的绝对变化量太小, 为了清晰显示边界, 我们对光强度数据均做了归一化处理, 宽度测量结果记录于表 1 。 

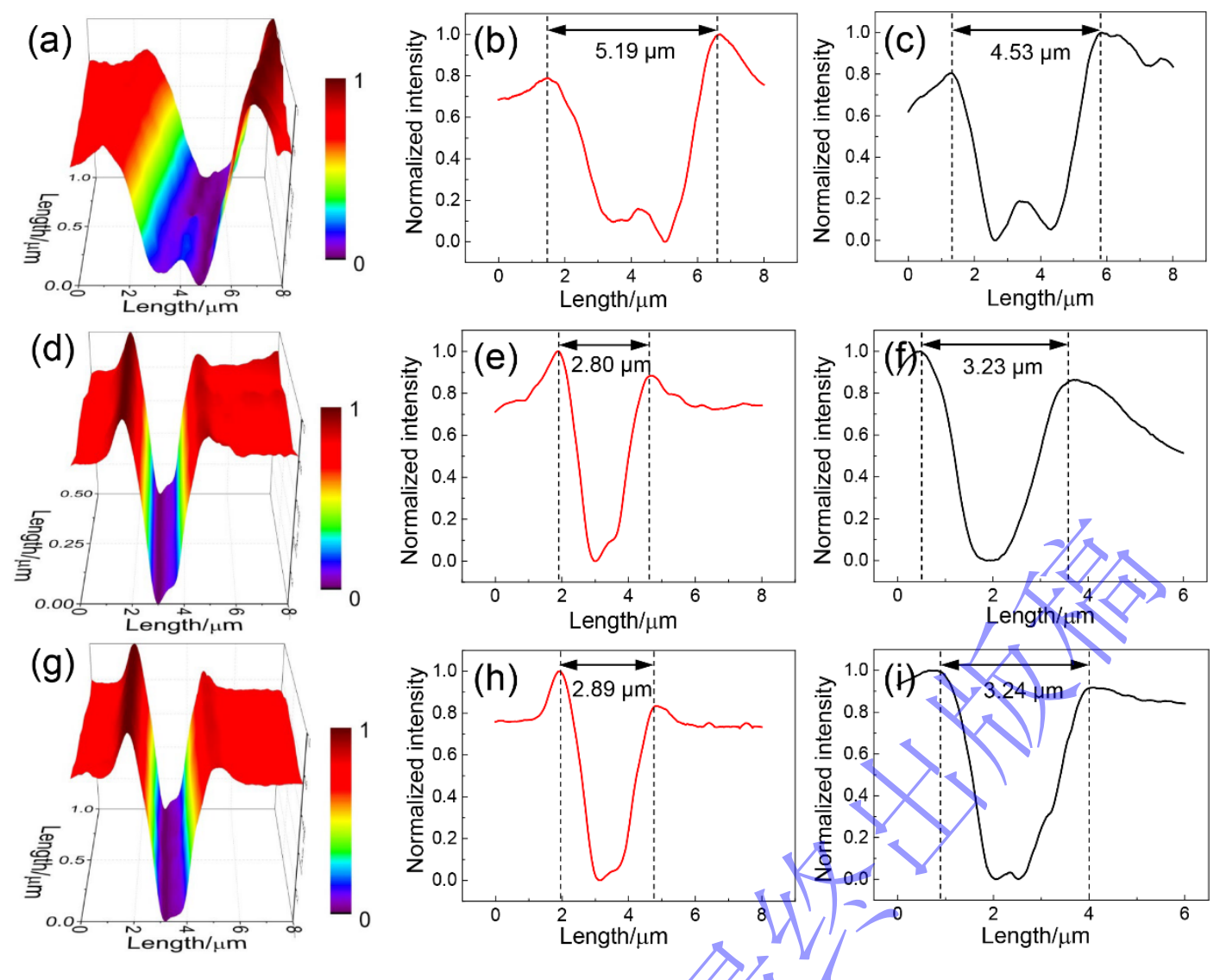

图 5 夹角 $\theta=23^{\circ}$ 时, 纳米线/锥形微光纤探针与唛统堆形光纤探针对 S1-S3 样品的宽度 测量值。(a)、(d)、(g) 分别为纳米线/雉形微光㭔探针对 S1-S3 样品扫描的成像图; (b)、(e)、 (h)分别为对应样品宽度的归一化测量结果; (c) (f)、 (i) 同样条件下, 锥形光纤探针对 S1-S3 样品宽度的归一化测量结果.

Fig. 5 The width measurement results of S1- S3 samples with the nanowire/tapered microfiber probe and traditional tapered microfiber probe at $\theta=23^{\circ}:(\mathrm{a})(\mathrm{d})(\mathrm{g})$ Imaging results of the samples S1-S3 scanned by the nanowire/tapered microfiber probe; (b)(e)(h) Measurement results of the width of the samples S1-S3 by the nanowire/tapered microfiber probe; (c)(f)(i)

Measurement results of the width of the samples S1-S3 by tapered microfiber probe.

实验采用 AFM的测量结果作为标准, 同样采用 $23^{\circ}$ 夹角的收集方向, 当收集 端为雉形微光纤探针时, 测量误差为 $17.40 \%-23.75 \%$, 最大误差值为 $1.05 \mu \mathrm{m}$; 当收集端为 CdS 纳米线/雉形微光纤探针时, 测量误差降低为 $4.71 \%-7.28 \%$, 最 大误差值为 $0.39 \mu \mathrm{m}$, 测量精度提高了约 3 倍。该扫描测量误差主要来自于基底 平台的水平度误差、纳米线的放置角度误差, 和纳米线悬臂抖动等机械误差引起 的探针与样品表面光场的相互作用改变, 以及环境背景光噪声等引起的检测误差。 相比于单独使用雉形光纤探针, 被动式 $\mathrm{CdS}$ 纳米线/雉形微光纤探针对光场的强 约束力可有效提高其近场扫描成像系统的检测精度。通过进一步地控制样品与探 
针的位置以及反射光场的稳定度，可有效提高探针收集光强信号的信噪比，最终 提高被动扫描成像系统的样品成像质量。

表 $1 \mathrm{CdS}$ 纳米线/锥形微光纤探针与传统雉形光纤探针测量结果对比

Table 1. Comparison of measurement results between $\mathrm{CdS}$ nanowire/tapered microfiber probe and traditional tapered microfiber probe

\begin{tabular}{|c|c|c|c|c|c|c|c|}
\hline \multirow{3}{*}{ 样品 } & \multirow{3}{*}{$\begin{array}{c}\mathrm{AFM} / \\
\mu \mathrm{m}\end{array}$} & \multirow{2}{*}{\multicolumn{2}{|c|}{$\begin{array}{c}\text { 雉形光纤探针 } \\
\theta=23^{\circ}\end{array}$}} & \multicolumn{4}{|c|}{$\mathrm{CdS}$ 纳米线/锥形光纤探针 } \\
\hline & & & & \multicolumn{2}{|c|}{$\theta=23^{\circ}$} & \multicolumn{2}{|c|}{$\theta=38^{\circ}$} \\
\hline & & $\begin{array}{c}\text { 测量结果 } \\
/ \mu \mathrm{m}\end{array}$ & 误差 & $\begin{array}{c}\text { 测量结果 } \\
/ \mu \mathrm{m}\end{array}$ & 误差 & $\begin{array}{c}\text { 测量结果 } \\
/ \mu \mathrm{m}\end{array}$ & 误差 \\
\hline $\mathrm{S} 1$ & 5.58 & 4.53 & $18.82 \%$ & 5.19 & $6.99 \%$ & 4.78 & $14.33 \%$ \\
\hline $\mathrm{S} 2$ & 2.61 & 3.23 & $23.75 \%$ & 2.80 & $7.28 \%$ & & $4.56 \%$ \\
\hline $\mathrm{S} 3$ & 2.76 & 3.24 & $17.40 \%$ & 2.89 & $4.71 \%$ & 3. & $42.75 \%$ \\
\hline
\end{tabular}

此外, 实验还研究了 $\mathrm{CdS}$ 纳米线/雉形光纤探针和样品的夹角 $\theta$ 对扫描成像 结果的影响。当收集端探针与样品的夹角增加为 $38^{\circ}$ 时, $\mathrm{CdS}$ 纳米线/雉形微光纤 探针系统的测量误差急剧升高，甚至达到了 42.75\% ; 而仅用雉形光纤探针已难以 得到准确的测量数值。在整个实验过程中，纳米线锥形微光纤探针的检测精度总 是高于传统的雉形光纤探针。

\section{4 结论}

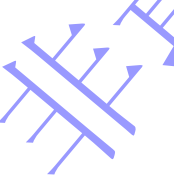

本文提出了一种基于 $\mathrm{CdS}$ 纳米线/雉形微光纤探针结构的被动式近场光学扫 描成像系统，该系统不需要激光激发等复杂光路，仅采用显微镜自身光源聚焦照 亮样品, 通过样品表面反射光强随样品表面起伏及突变边界的改变, 对样品进行 形貌扫描成像。CdS 纳米线的高折射率，提高了探针对待测光场的束缚能力，实 现了 $4.65 \%$ 的理论探针收集效率, 相比于传统的金属镀膜近场探针收集效率提高 了一个数量级。最终通过光强变化实现对目标样品的扫描成像, 测量误差降低为 $4.71 \%-7.28 \%$ 。该方案相比于纳米发光探针方案，降低了探针的制备难度和系统 整体检测结构的复杂性; 相比传统的雉形光纤探针方案，扫描成像精度提高了约 3 倍。此外, 实验结果还表明该被动式扫描探针与样品夹角 $\theta$ 的增加会降低系统 的成像精度，但是纳米线/雉形微光纤探针的检测精度总是高于传统雉形光纤探针。 
此外, 实验方案中较大的显微聚焦照明区域也避免了光斑面积对成像范围的限制, 其成像范围仅由纳米位移台的行程决定。该被动式近场光学扫描方案的系统结构 更加简洁, 操作也更简单, 为以后的近场光学扫描显微系统的改进提供了新思路。

\section{参考文献}

[1] Trautman J K, Macklin J J, Brus L E, Betzig E. 1994 Nature 36940

[2] Betzig E, Trautman J K. 1992 Science 257189

[3] Ruckstuhl T, Verdes D, Winterflood C M, Seeger S. 2011 Opt. Express 196836.

[4] Hu R X, Pan B Y, Yang Y L, Zhang W H. 2017 Acta. Phys Sin. 66 144209. (in Chinese) [胡睿璇，潘冰洋. 杨玉龙，张伟华 2017 物理学报 66 144209]

[5] Rayleigh L.1896 On the theory of optical images, with special reference to the microscope (Cambridge University Press, Cambridge, 1903) p167

[6] Betzig E, Trautman J K, Harris T D, Weiner J S, Kostelak R L. 1991 Science 251 1468.

[7] Hermann R J, Gordon M J. 2018 Annu. Rev. Chem. Biomol. 9365.

[8] Novotny L, Stranick J S. 2006 Annu. Rev. Phys. Chem. 57303.

[9] Kalkbrenner T, Ramstein M, Mlynek J, Sandoghdar V. 2001 J. Microsc. 20272.

[10] Bharadwaj R, Novotny L. 2007 Opt. Express 1514266.

[11] Kim Z/H, Zeeone S R. 2006 J. Phys. Chem. B 11019804.

[12] Sun L, Bai B , Meng X, Cui T, Shang G, Wang J. 2018. Opt. Express 2624637.

[13] Novotny L, Hulst N V. 2011 Nature Photon. 583.

[14] Palomba S, Novotny L. 2009 Nano Lett. 93801.

[15] Hoeppener C, Lapin Z J, Bharadwaj P, Novotny L. 2012. Phys. Rev. Lett. 109 017402. 
[16] Pan B, Yang Y, Bian J, Hu X, Zhang W. 2019 Opt. Commun. 445273.

[17] Wei B, Melli M, Caselli N; Riboli F, Wiersma D S, Staffaroni M, Choo H, Ogletree F, Aloni S, Bokor J, Cabrini S, Intonti F, Salmeron M B, Yablonovitch E, Schuck P J, Weber-Bargioni A. 2012 Science 3381317.

[18] Wu X Q, Wang Y P, Tong L M. 2015 Physics 44 356. (in Chinese) [伍晓芹，王依 䨌，童利民 2015 物理 44356$]$

[19] Gu F X 2012 Ph. D. Optical waveguiding nanowires and their sensing application (Hangzhou: Zhejiang University) (in Chinese) [谷付星 2012 博本学位论文 (杭 州:浙江大学)]

[20] Kim S, Yu N, Ma X, Zhu Y Z, Liu Q S, Liu M, YanR X. 2019. Nature Photon. 13 636.

[21] Wu Y K, Liu X J, Qi X Z, Lu L, Guo G, P, Guo G C, Ren X F. 2021 Appl. Phys. Lett. 118104002.

[22] Huang K, Yang S Tong L. 2007 Appl. Opt. 461429.

[23] Marcatili E. 1986 IEEE J Quantum Electron. 22988.

[24] Liao F, Wang Y, Peng T, Peng J, Gu Z Q, Yu H K, Chen T, Yu J X, Gu F X. 2018 Adv. Opt. Mater. 61701012.

[25] Linghu S Y, Gu Z Q, Lu J S, Fang W, Yang Z Y, Yu H K, Li Z Y, Zhu R L, Peng J, Zhan Q W, Zhuang S L, Gu M, Gu F X. 2021 Nat. Commun. 121.

[26] Wang G J , Wu S F, Li X F, Li R, Duan J M , Pan S. 2010 Acta. Phys. Sin. 59192 (in Chinese) [王国军，吴世法，李旭峰，李睿，段建民，潘石. 2010 物理学报 59 192]

[27] Zhang M Q, Wang J, Tian Q. 2013 Chin. Phys. B. 22044202. 
[28] Wang J, Wu X Y, Sun L, Zhou B K 2016 Scanning near-field optical microscope and nano-optical measurement .(Beijing: science press) p167 and p247(in Chinese) [王佳,武晓宇,孙琳, 周炳琨 2016 扫描近场光学显微镜和纳米光学测量. (北京: 科 学出版社）第 167 页和第 247 页]

[29] Shi S X, Wang X E, Ma L 2014 Physical optics and applied optics .(Xi'an: Xidian University Press) p31 and p77(in Chinese) [石顺祥,王学恩,马琳 2014 物理光学与 应用光学.(西安：西安电子科技大学出版社) 第 31 页和第 77 页] [30] Yu J X, Liu F, Gu Z Q, Gu F X, Zhuang S L. 2018 Opt. Express 266880.
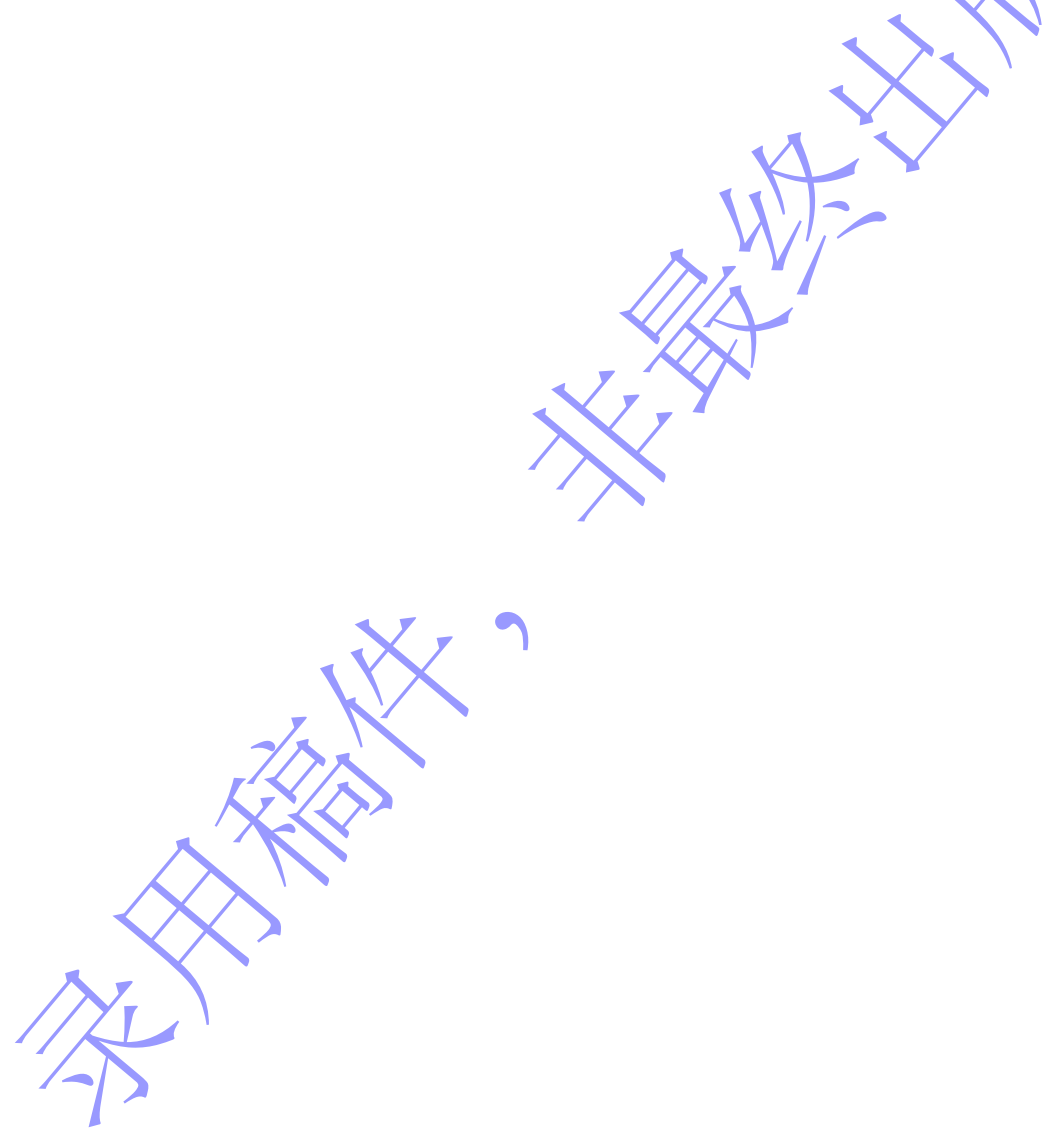
Research on Passive Near-field Optical Scanning Imaging Based on Semiconductor Nanowire/Tapered Microfiber Probe*

Dou Lin ${ }^{1)} \quad$ Ma Yanna $^{1)^{\dagger}}$ Gu Zhaoqi ${ }^{1)}$ Liu Jiatong ${ }^{1)}$ Gu Fuxing ${ }^{1)}{ }^{\dagger}$ ( School of Optical-Electrical and Computer Engineering, University of Shanghai for Science and Technology, Shanghai 200093, China)

Abstract:

In this paper, we propose a passive near-field scanning imaging system by using the structure of cadmium sulfide $(\mathrm{CdS})$ nanowire/tapered microfiber probe, which combines the near-field scanning structure and the nanowire/microfiber coupling technology. The păssive,near-field scanning imaging system adopts a passive nanoprobe to detect the intensity change of the reflected light field on the sample surface, which not only retains the advantage of the nanoprobe for the strong restriction of the reflected light on the sample surface, but also reduces the interference of strong excitation light during detection. Through the high efficiently evanescent field coupling between the CdS nanowire and the tapered microfiber, the collected light signal is transmitted to the photodetector at the far field, and finally the imaging of the target sample morphology can be realized.

At first, the light field model of the nanowire/tapered microfiber probe structure is verified by the finite element analysis method. The calculated collection efficiency from the sample to the probe is about $4.65 \%$ and the transmission efficiency from the nanowire to the tapered microfiber is about $74.47 \%$. The collection efficiency is improved by an order of 
magnitude compared with traditional metal-coated near-field probe. In the experiments, a scanning step of $20 \mathrm{~nm}$ and a probe-sample distance of 230 $\mathrm{nm}$ were selected. The nanowire/tapered microfiber probe and traditional tapered fiber probe are both used to measure the width of different CdSe nanoribbons samples and the atomic force microscopy measurement are used as the benchmark to calculate their measurement error, which is increased by about 3 times. By changing the angle $\theta$ between the probe and the sample on the imaging quality, it is found that the resolution obtained using the designed nanowire/microfiber probe is always higher than that only using the tapered microfiber probe. Compared with the tapered microfiber probe scheme, the measurement error is reduced to be less than $7.2 \%$.

In addition, compared with the active luminescence probe scheme, this passive near-field scanning scheme reduces the preparation complexity of the optical probe and the detection structure complexity of the optical system. The large microscopic illumination area can avoid the influence of the small laser spot size on imaging, and the imaging range is only determined by the travel distance of the linear stage. Therefore, our work may provide an attractive approach for developing new near-field scanning microscopy systems in the future.

Keywords: Near-field optical scanning, passive microscopy imaging technology,

nanowire/microfiber optical probe, cadmium sulfide nanowire, evanescent field coupling

* Project supported by the Excellent Youth Science Fund Project of National Natural Science Foundation of China (Grant Nos. 6212200740). 